\title{
Development of Low-calorie Functional Yoghurt by Incorporating Mannitol Producing Lactic Acid Bacteria (Leuconostoc pseudomesenteroides) in the Standard Yoghurt Culture
}

\author{
Lejaniya Abdul Kalam Saleena ${ }^{1}$, Deepak Chandran ${ }^{2 *}$ (D), Geetha Rayirath ${ }^{3}$, \\ Arjun Shanavas $^{4}$, Sureshkumar Rajalingam ${ }^{5}$ (D) , Marthandan Vishvanathan ${ }^{6}$, \\ Khan Sharun ${ }^{7 *}$ (iD) and Kuldeep Dhama ${ }^{8}$ (D)
}

\begin{abstract}
${ }^{1}$ Department of Food Science and Nutrition, UCSI University, Faculty of Applied Sciences, 1, UCSI Heights, Jalun Pancak Menara Gading, Taman Connaught, 56000 Cheras, Willayah Persekutuan Kuala Lampur, Malaysia. ${ }^{2}$ Department of Veterinary Sciences and Animal Husbandry, Amrita School of Agricultural Sciences, Amrita Vishwa Vidyapeetham University, Coimbatore - 642 109, Tamil Nadu, India.

${ }^{3}$ Department of Dairy Science, College of Veterinary \& Animal Sciences, Kerala Veterinary \& Animal Sciences University, Mannuthy, Thrissur - 680 651, Kerala, India.

${ }^{4}$ Division of Medicine, ICAR-Indian Veterinary Research Institute, Bareilly - 243122, Uttar Pradesh, India.

${ }^{5}$ Department of Agronomy, Amrita School of Agricultural Sciences, Amrita Vishwa Vidyapeetham University, Coimbatore - 642 109, Tamil Nadu, India.

${ }^{6}$ Department of Seed Science and Technology, Amrita School of Agricultural Sciences, Amrita Vishwa Vidyapeetham University, Coimbatore - 642109, Tamil Nadu, India.

${ }^{7}$ Division of Surgery, ICAR-Indian Veterinary Research Institute, Bareilly - 243 122, Uttar Pradesh, India.

${ }^{8}$ Division of Pathology, ICAR-Indian Veterinary Research Institute, Bareilly - 243 122, Uttar Pradesh, India.
\end{abstract}

\footnotetext{
*Correspondence: c_deepak@cb.amrita.edu; sharunkhansk@gmail.com

(Received: February 13, 2022; accepted: February 27, 2022)
}

Citation: Saleena LAK, Chandran D, Rayirath G, et al. Development of Low-calorie Functional Yoghurt by Incorporating Mannito Producing Lactic Acid Bacteria (Leuconostoc pseudomesenteroides) in the Standard Yoghurt Culture. J Pure Appl Microbiol. 2022;16(1):729-736. https://doi.org/10.22207/JPAM.16.1.78

(C) The Author(s) 2022. Open Access. This article is distributed under the terms of the Creative Commons Attribution 4.0 International License which permits unrestricted use, sharing, distribution, and reproduction in any medium, provided you give appropriate credit to the original author(s) and the source, provide a link to the Creative Commons license, and indicate if changes were made. 


\begin{abstract}
As calorie-consciousness becomes a worldwide phenomenon, demand for low-calorie sweeteners is increasing. Compared to other sugars, the reduced calorific value of mannitol (1.6 kilocalories per gram) finds its application as a sweetener in low-calorie foods. The present study was conducted to develop low-calorie yoghurt by adding lactic acid bacteria (LAB) having significant mannitol production potential. Leuconostoc pseudomesenteroides IMAU:11666 was incorporated to standard yoghurt culture as adjunct culture. As mannitol is a food-grade sweetener with Food and Drug Administration (FDA) endorsement, the newly identified LAB strain can be used to develop low-calorie dairy products with beneficial effects. Side effects of other artificial sweeteners can also be reduced. Significantly high ( $p \leq 0.05)$ mannitol content was observed in functional yoghurt samples T1 $(12.27 \pm 0.18 \mathrm{~g} / \mathrm{I})$ and $\mathrm{T} 2(14.13 \pm 0.30 \mathrm{~g} / \mathrm{l})$ with Leuconostoc pseudomesenteroides when compared to control samples. The calorific value obtained for yoghurt samples viz., C1, C2, T1, and T2 $(86,95,98$, and $92 \mathrm{kcal} / 100 \mathrm{~g}$, respectively) was less than control yoghurt $C$ ( $99 \mathrm{kcal} / 100 \mathrm{gm})$. Microbial and chemical quality parameters of the functional yoghurt were in the safe and acceptable zone. On sensory evaluation of yoghurt samples, significantly higher overall and flavor scores were observed for sample T2 with Leuconostoc pseudomesenteroides.
\end{abstract}

Keywords: Mannitol, Leuconostoc pseudomesenteroides, Yoghurt, Calorific value, Microbial quality, Sensory quality

\section{INTRODUCTION}

Governments worldwide have been issuing science-based dietary advice for more than a century, regularly changing their recommendations to avoid nutritional shortages, reduce the risk of chronic illness, and enhance human health. ${ }^{1}$ Despite these efforts, worldwide malnutrition and non-communicable disease (NCD) trends continue to rise. In addition, several countries lost the ability to achieve their health and sustainability goals due to these fully avoidable diet-related health outcomes. ${ }^{2}$ Dairy products are widely consumed in many parts of the world and are a good source of protein and minerals. ${ }^{3,4}$ On the other hand, dairy products contain ingredients that may cause health problems, such as cholesterol and saturated fatty acids (SFAs). However, the combination of SFAs found in dairy does not increase cardiometabolic risk as much as other diets. The interplay of multiple ingredients and processing aspects produces varying outcomes in association studies examining the volume and type of dairy foods with type 2 diabetes risk. ${ }^{5}$ This is where the importance of low-calorie dairy food formulation and development comes into play. ${ }^{3}$

D-Mannitol is a sugar alcohol with six-carbon, half sweet as sucrose, and has diverse applications in low-calorie foods and pharmaceuticals. ${ }^{6}$ Mannitol imparts a cold, sweet flavour to meals, with sucrose accounting for around half of the sweetness. Mannitol does not dramatically raise the level of blood sugar, resulting in a lower glycemic index, making it beneficial to people with diabetes. ${ }^{7}$ Lactic acid bacteria (LAB) are considered food-grade microorganisms with Generally Recognized as Safe (GRAS) status. ${ }^{8}$ These microorganisms and their products can be added to foods without any restriction due to their beneficial effect on the gastrointestinal tract. In addition, mannitol produced by such food-grade organisms can act as a natural sweetener in food products and is therefore considered to be the alternative to artificial sweeteners. ${ }^{9}$

A Leuconostoc citreum strain was previously isolated from sourdoughs and used as a starter in apple juice. After 48 hours of fermentation, the sucrose and fructose concentrations in the apple juice were dramatically reduced $(83 \%)$ with a concurrent increase in mannitol concentration. As a result, it had less sugars but retained sweetness, indicating that converting fructose to mannitol might lead to healthier drinks. ${ }^{10}$ Moreover, it is a food-grade sweetener with Food and Drug Administration (FDA) endorsement with ADI of $0-50 \mathrm{mg} / \mathrm{kg}$ body weight.

The present study was conducted to develop low-calorie yoghurt by adding mannitol- 
producing lactic acid bacteria Leuconostoc pseudomesenteroides to the standard culture. In addition, chemical, microbiological and sensory parameters of yoghurt were also studied.

\section{MATERIALS AND METHODS}

Preparation of functional yoghurt

Yoghurt was prepared according to

Tamime and Robinson. ${ }^{11}$ The cultures used in different treatment yoghurt samples are mentioned in Table 1.

\section{Estimation of calorific value}

The calorific values were estimated at Confederation for Ayurvedic Renaissance Keralam Ltd (CARE, Keralam) laboratory, Thrissur, Kerala, using formula method.

The equation used was: $\mathrm{kcal} 100 \mathrm{~g}-1=(\%$ protein $\times 4)+(\%$ lactose $\times 4)+(\%$ fat $\times 9)$.

\section{Chemical analysis}

\section{Titratable acidity}

Ten grams of yoghurt sample was weighed in a suitable dish or basin. To this, $30 \mathrm{ml}$ of warm water and $1 \mathrm{ml}$ of phenolphthalein indicator were also added. Sample along with reagents mixed well and titrated against $0.1 \mathrm{~N} \mathrm{NaOH}$ solution. 10 $\mathrm{g}$ of material diluted with $30 \mathrm{ml}$ of water taken in another dish served as a control for comparison of colour.

pH

$\mathrm{pH}$ was measured using an electronic digital type $\mathrm{pH}$ meter Hanna. ${ }^{12}$ Syneresis

The yoghurt ( $10 \mathrm{~g}$ ) was spread across the Whatman No. 1 filter paper as a thin layer to cover the surface. The yoghurt was filtered for a period of $10 \mathrm{~min}$. The quantity of liquid that passed through the filter paper was estimated and recorded. The percentage of syneresis was calculated by dividing the weight of the liquid passed with the weight of the initial sample multiplied by $100 .{ }^{13}$

\section{Microbiological analysis LAB count}

Enumeration of $L A B$ in the yoghurt sample was carried out (IDF, 117: 2003) in selective media for Lactobacillus delbrueckii sub-sp. bulgaricus (MRS media) and for Streptococcus thermophillus (M-17 media). Serial dilutions of the samples were prepared using peptone diluents. Yoghurt samples were plated at $10^{-2}, 10^{-4}, 10^{-6}$, and $10^{-7}$ dilution and incubated at $37^{\circ} \mathrm{C}$ for $48 \mathrm{~h}$.

\section{Coliform count}

Direct samples were decimally diluted at $10^{-1}$ in sterile peptone water and plated $1 \mathrm{ml}$ sample with $20 \mathrm{ml}$ of VRBA plated into Petri dishes for enumeration of coliform bacteria as coliform colony forming units per millilitre by pour plate method. Plates were incubated at $37^{\circ} \mathrm{C}$ for 24 hours. ${ }^{14}$

\section{Yeast and mould count}

Potato dextrose agar plates were prepared with $10 \%$ tartaric acid. Spread plating technique was adopted by spreading $0.1 \mathrm{ml}$ of direct and $10^{-1}$ diluted sample over sterile plates. Plates were incubated at $25^{\circ} \mathrm{C}$ for five days. The development of colonies was observed.

\section{Sensory evaluation}

Sensory evaluation of yoghurt samples was carried out using a nine-point hedonic scale. ${ }^{15}$ Scorecard was also prepared. Different sensory parameters such as appearance and colour, body and texture, flavour, and overall scores were analyzed.

\section{Statistical analysis}

Six replications were carried out, and the data obtained was subjected to statistical analysis using SPSS version 24.0. Non-parametric tests and one-way ANOVA were used to evaluate the sensory parameters of yoghurt.

Table 1. Different treatments of yoghurt prepared for analysis

\begin{tabular}{ll}
\hline Treatments & Details of starter lactic acid bacteria added \\
\hline Control 1 (C) & Standard yoghurt cultures (Streptococcus thermophilus, Lactobacillus bulgaricus) \\
Control 2 (C1) & Standard yoghurt cultures + Leuconostoc mesenteroides \\
Control $3(\mathrm{C} 2)$ & Standard yoghurt cultures + Leuconostoc mesenteroides+ optimum sugar \\
Treatment (T1) & Standard yoghurt cultures + Leuconostoc pseudomesenteroides \\
Treatment (T2) & Standard yoghurt cultures + Leuconostoc pseudomesenteroides + optimum sugar
\end{tabular}




\section{RESULTS}

Estimation of mannitol content and calorific value in functional yoghurt

Estimation of mannitol content in functional yoghurt samples, colorimetric assay with slight modifications was performed as per the method suggested by Sanchez. ${ }^{16}$ Yoghurt samples prepared were given in Table 1. Comparison of mannitol content in Control yoghurt samples (C1 \& C2) and treatments (T1 \& T2) were carried out. Overall mean mannitol content was estimated as $7.67 \pm 0.31,6.13 \pm 0.18,12.27 \pm 0.18$ and 14.13 $\pm 0.30 \mathrm{~g} / \mathrm{l}$ respectively for $\mathrm{C} 1, \mathrm{C} 2, \mathrm{~T} 1$ and $\mathrm{T} 2$. A significant increase $(p \leq 0.05)$ in mannitol content was observed in treatment groups $\mathrm{T} 1$ and $\mathrm{T} 2$ than $\mathrm{C} 1$ and $\mathrm{C} 2$, which indicates that the functional yoghurt with Leuconostoc pseudomesenteroides shows higher mannitol production.

The calorific value of functional yoghurt was estimated in CARE Keralam laboratory, Thrissur, and compared with control, and the result is depicted in Table 2. The value observed for plain yoghurt prepared with standard cultures S. thermophillus and L. bulgaricus was $99 \mathrm{kcal}$ in $100 \mathrm{gm}$. The calorific value obtained for C1, C2, T1, and $\mathrm{T} 2$ were $86,95,98$, and $92 \mathrm{kcal}$, respectively, in $100 \mathrm{gm}$ using a bomb calorimeter. It was clear

Table 2. Calorific value of yoghurts

\begin{tabular}{lc}
\hline Yoghurt samples & $\begin{array}{r}\text { Calorific Value } \\
\text { (kcal/100gm) }\end{array}$ \\
\hline C (S. thermophillus and L. bulgaricus) & 99 \\
C1 (S. thermophillus, L. bulgaricus and & 86 \\
L. mesenteroides) & \\
C2 (C1 and sugar 4 per cent) & 95 \\
T1 (S. thermophillus, L. bulgaricus and & 98 \\
L. pseudomesenteroides) & \\
T2 (T1 and sugar 4 per cent) & 92 \\
\hline
\end{tabular}

that the functional yoghurt with Leuconostoc pseudomesenteroides and optimum sugar produce low caloric yoghurt than normal standard yoghurt. Chemical analysis

The result of titratable acidity, $\mathrm{pH}$, and syneresis were given in Table 3 for samples $C, C 1$, $C 2, T 1$, and $T 2$. A significant difference $(p \leq 0.05)$ in acidity and $\mathrm{pH}$ was observed among the samples. In addition, freshly prepared yoghurt samples were examined for syneresis. Statistical analysis using one-way ANOVA ( $p$-value $\leq 0.05$ ) showed a significant difference between the treatment samples.

\section{Microbiological analysis}

Lactic count obtained (Streptococcus thermophilus and Lactobacillus bulgaricus), coliform count, and yeast and mould count obtained were given in Table 4. The mean Streptococcus count observed in C, C1, C2, T1, and $\mathrm{T} 2$ were $7.62 \pm 0.01,7.81 \pm 0.01,7.8 \pm 0.01$, $7.74 \pm 0.01$, and $7.87 \pm 0.01$ at log cfu/g, respectively. Concerning L. bulgaricus count, the mean count observed in C, C1, C2, T1, and T2 were 7.62 \pm 0.02 , $5.71 \pm 0.03,5.36 \pm 0.03,3.28 \pm 0.02$, and $2.36 \pm 0.03$ $\log \mathrm{cfu} / \mathrm{g}$. The entire control and treatment yoghurt samples showed the absence of coliform in direct plating. No significant difference was noted in any of the samples used for yeast and mould count.

\section{Sensory evaluation}

Overall score obtained for C, C1, C2, T1 and T2 were $14.63 \pm 0.40,15.49 \pm 0.51,16.97 \pm$ $0.56,15.63 \pm 0.45$ and $18.35 \pm 0.54$ respectively. The score obtained shows that the sample T2 had a higher value and was comparatively more acceptable by the panelist with its appearance, colour, body, texture, and flavour. On nonparametric test analysis, the $p$-value was $\leq 0.05$, indicating a significant difference between different yoghurt samples with respect to overall

Table 3. Chemical quality of yoghurt samples

\begin{tabular}{lcccccc}
\hline Chemical parameters & \multicolumn{3}{c}{ Control } & & \multicolumn{2}{c}{ Treatment } \\
\cline { 2 - 3 } \cline { 6 - 7 } & C & C1 & C2 & & T1 & T2 \\
\hline $\begin{array}{l}\text { Titratable acidity } \\
\text { (Per cent of lactic acid) }\end{array}$ & $0.72 \pm 0.01^{\mathrm{c}}$ & $0.75 \pm 0.00^{\mathrm{b}}$ & $0.73 \pm 0.01^{\mathrm{cb}}$ & & $0.74 \pm 0.00^{\mathrm{cb}}$ & $0.79 \pm 0.00^{\mathrm{a}}$ \\
pH & & & & & \\
Syneresis (\%) & $4.59 \pm 0.03^{\mathrm{ab}}$ & $4.51 \pm 0.01^{\mathrm{b}}$ & $4.60 \pm 0.03^{\mathrm{a}}$ & & $4.58 \pm 0.03^{\mathrm{ab}}$ & $4.52 \pm 0.01^{\mathrm{b}}$ \\
& $27.17 \pm 0.88^{\mathrm{a}}$ & $25.92 \pm 0.50^{\mathrm{a}}$ & $20.45 \pm 1.05^{\mathrm{c}}$ & & $23.35 \pm 0.88^{\mathrm{b}}$ & $14.08 \pm 0.81^{\mathrm{d}}$ \\
\hline
\end{tabular}

Each value is a mean of six observations with $\mathrm{SE}$

Means with different superscript in same rows differ significantly $(p \leq 0.05)$. 
Table 4. Microbial quality of yoghurt samples

\begin{tabular}{|c|c|c|c|c|c|}
\hline \multirow{3}{*}{$\begin{array}{l}\text { Lactic acid bacteria } \\
\text { cultures }\end{array}$} & \multicolumn{3}{|c|}{ Microbial counts } & & \\
\hline & \multicolumn{3}{|c|}{ Control (log cfu/g) } & \multicolumn{2}{|c|}{ Treatment (log cfu/g) } \\
\hline & $\mathrm{C}$ & $\mathrm{C} 1$ & $\mathrm{C} 2$ & $\mathrm{~T} 1$ & $\mathrm{~T} 2$ \\
\hline S. thermophilus counts & $7.62 \pm 0.01^{d}$ & $7.81 \pm 0.01^{b}$ & $7.8 \pm 0.01^{b}$ & $7.74 \pm 0.01^{c}$ & $7.87 \pm 0.01^{\mathrm{a}}$ \\
\hline L. bulgaricus counts & $7.62 \pm 0.02^{\mathrm{a}}$ & $5.71 \pm 0.03^{b}$ & $5.36 \pm 0.03^{b}$ & $3.28 \pm 0.02^{c}$ & $2.36 \pm 0.03^{d}$ \\
\hline Coliform count & NIL & NIL & NIL & NIL & NIL \\
\hline Yeast and mould counts & $0.49 \pm 0.04^{\mathrm{ns}}$ & $0.48 \pm 0.10^{\text {ns }}$ & $0.51 \pm 0.06^{\mathrm{ns}}$ & $0.48 \pm 0.07^{\mathrm{ns}}$ & $0.48 \pm 0.05^{\text {ns }}$ \\
\hline
\end{tabular}

Each value is a mean of six observations with SE; Means with different superscript in same row differ significantly $(p \leq 0.05)$; ns - non significant $(p>0.05)$.

Table 5. Sensory scores of functional yoghurts

\begin{tabular}{lccc}
\hline \multirow{2}{*}{$\begin{array}{c}\text { Yoghurt } \\
\text { samples }\end{array}$} & \multicolumn{3}{c}{ Sensory scores } \\
\cline { 2 - 4 } & Appearance and colour & Body and texture & Flavour \\
\hline C & $4.00 \pm 0.10^{\text {ns }}$ & $3.75 \pm 0.20^{\text {ns }}$ & $6.86 \pm 0.22^{\text {bc }}$ \\
C1 & $4.04 \pm 0.17^{\text {ns }}$ & $3.91 \pm 0.18^{\text {ns }}$ & $7.53 \pm 0.20^{\mathrm{d}}$ \\
C2 & $4.03 \pm 0.16^{\text {ns }}$ & $4.05 \pm 0.16^{\text {ns }}$ & $8.89 \pm 0.26^{\mathrm{c}}$ \\
T1 & $4.25 \pm 0.14^{\text {ns }}$ & $4.17 \pm 0.17^{\text {ns }}$ & $7.19 \pm 0.26^{\mathrm{a}}$ \\
T2 & $4.47 \pm 0.18^{\text {ns }}$ & $4.46 \pm 0.16^{\text {ns }}$ & $9.39 \pm 0.25^{\text {ab }}$ \\
\hline
\end{tabular}

Each value is a mean of six observations with SE; Means with different superscript in same column differ significantly $(p \leq 0.05)$; $n s-$ non significant $(p>0.05)$.

mean scores. No significant differences were noticed in scores of different samples related to appearance and colour and body and texture (Table 5). However, a significant increase in flavour score was noted in sample $\mathrm{T} 2$.

\section{DISCUSSION}

Estimation of mannitol content and calorific value in functional yoghurt

Otgonbayar et al. ${ }^{17}$ evaluated the mannitol production of different Leuconostoc strains isolated from kimchi. They discovered that the strain L. citreum KACC 91348P grew faster (high growth rate) and generated more mannitol (high production rate) than the other strains. The mannitol production was reported to be maximum $(14.83 \mathrm{~g} / \mathrm{L} / \mathrm{h})$ when it was grown in a batch fermenter $\left(30^{\circ} \mathrm{C}\right.$ and $\left.\mathrm{pH} 6.5\right)$. Jung et al..$^{18}$ made baechu kimchi, fermented traditional Korean vegetable cuisine with a mannitol-producing L. mesenteroides strain ( $10^{7}$ cells/g kimchi) as the starter. The mannitol level of starter kimchi was greater than that of non-starter kimchi. So far, there haven't been any reports of kimchi fermenting with fructose added on purpose. The addition of fructose to kimchi is expected to increase the formation of mannitol. Rice et al. ${ }^{19}$ described a novel use of a Leuconostoc strain to create a healthful beverage. Helanto et al. ${ }^{20}$ used chemical treatment to create a Leuconostoc pseudomesenteroides mutant with a fructokinase activity of only $10 \%$ of the wild-type. In the presence of glucose and fructose, the mutant generated more mannitol than the wild type. This is because of the blocking of fructose 6-phosphate production, and more fructose was transformed into mannitol.

Dwivedi ${ }^{21}$ observed that mannitol intake would be slightly laxative if it exceeded $20 \mathrm{~g}$ per day. Mannitol is a food-grade sweetener with Food and Drug Administration (FDA) endorsement with ADI of $0-50 \mathrm{mg} / \mathrm{kg}$ body weight. The mannitol content observed in the current research meets the above-mentioned recommendation. Previous research used different techniques in the detection of mannitol from organic materials. Yun and $\mathrm{Kim}^{22}$ detected mannitol content with the help of HPLC (High-Performance Liquid Chromatogram) using a 
cation exchange resin column at $85^{\circ} \mathrm{C}$. Sanchez ${ }^{16}$ and Grobben et al. ${ }^{23}$ used the colorimetric assay method to detect mannitol from complex biological material. Chandan et al. ${ }^{24}$ estimated the amount of sugar alcohol content in the yoghurt sample and found it negligible in quantity compared with other mono and disaccharide sugars.

Benedict and Fox ${ }^{25}$ determined energy values of various foods and excreta by heat combustion using a bomb calorimeter. They estimated the calorific value of dried skimmed milk as 4.89 calories per litre of oxygen. The study conducted by Kroger and Weaver ${ }^{26}$ mentioned that the average calorific value of 44 yoghurt samples examined from central Pennsylvania ranged $62.3-127.0 \mathrm{kcal} / 100 \mathrm{~g}$ with an average of 103.2 $\mathrm{kcal} / 100 \mathrm{~g}$. The average calorific value of yoghurt lies between ice cream (200 kcal/100g) and whole milk (60 kcal/100g). The values obtained in the present study are in accordance with the reported values. $\mathrm{AOAC}^{27}$ detailed the method of estimating calorific value in feed and food samples using a bomb calorimeter. Smit et al. ${ }^{28}$ determined the calorific value of whole milk, milk with two percent fat, milk powder (skimmed), gouda cheese, cottage cheese, cheddar cheese, and cottage cheese using a bomb calorimeter. In the study conducted by Salman et al., ${ }^{29}$ the calorific values of buffalo milk $(p<0.05)$ were found to be higher than cow milk. Dairy Council of California reported the calorific content of low-fat plain yoghurt as $154 \mathrm{kcal}$ in $245 \mathrm{~g}$ of samples. The calorific value of plain whole milk yoghurt per $100 \mathrm{~g}$ is $61 \mathrm{kcal} .^{30}$

\section{Chemical analysis}

Younus et al. ${ }^{31}$ determined titratable acidity of three different brands of plain yoghurt, with AOAC method No. 947.05 (1990) and observed an acidity of $0.89,0.87$ and 1.13 percent lactic acid with standard deviation $0.02,0.04$, and 0.05 respectively. In a study conducted by Joseph et al., ${ }^{32}$ a pH range of 4.08-3.7 was observed for plain yoghurt and 4.11 - 4.10 for fruit yoghurt. The study conducted by Nazni and Komathi ${ }^{33}$ on papaya and banana pulp incorporated fruit yoghurt observed that $\mathrm{pH}$ was higher (6.3 and 6.8) when compared with control cow milk yoghurt and commercial yoghurt (4.5 and 4.9). According to Foda et al., ${ }^{34}$ prolonged yoghurt storage at low temperature $4^{\circ} \mathrm{C}$ decreased syneresis to half of its initial value compared with fresh yoghurt samples. Roy et al. ${ }^{35}$ conducted a study on yoghurt supplemented with fruit pulp and reported that syneresis decreased during the initial five days of storage and increased with an increase in period of storage in yoghurt. In this study, fresh control cow milk yoghurt had a syneresis percent of 48.5 .

\section{Microbiological analysis}

In the case of Lactobacillus bulgaricus, the count gets reduced in the present study. A significant difference was observed between control and treatment in both LAB counts. Adjunct culture might have influenced the growth of yoghurt cultures. This was in accordance with the research done by Ranasinghe and Perera, ${ }^{36}$ where Lactobacillus count was less than Streptococcus count in fresh yoghurt. Arnott et al. ${ }^{37}$ used the bacteriological media violet red bile agar (Difco) to detect coliforms. Plates were incubated at $37^{\circ} \mathrm{C}$ for $24 \mathrm{~h}$, and the result ranged from $<1$ to $110 \mathrm{cfu} / \mathrm{g}$. Mohammed and El Zubeir ${ }^{38}$ determined the yeast and mould count of powdered milk and fresh milk yoghurt as $5.78 \pm 1.56 \log 10 \mathrm{cfu} / \mathrm{ml}$ and $5.65 \pm 1.86$ $\log 10 \mathrm{cfu} / \mathrm{ml}$, respectively. As per FSSA standards, the yeast and mould count in fermented products should not exceed more than $100 \mathrm{cfu} / \mathrm{ml}$. Less than 10 log cfu/g in the current study indicate good sanitary condition.

\section{Sensory evaluation}

McGregor and White ${ }^{39}$ judged fruit flavoured yoghurt with various sweeteners and observed that yoghurt with no added sweetener had a significantly $(P<0.001)$ lower flavour score than the sweetened. All sweetened yoghurts scored good to excellent. In the present study, a significantly higher flavour score was observed for sweetened yoghurts than others. In a study on whether sucrose esters improved the quality of non-fat low-calorie yoghurt by Farooq and Haque, ${ }^{40}$ fat less low-calorie yoghurt sweetened with aspartame had a calorific value of $101.4 \mathrm{kcal}$ per 226.8g than regular yoghurt. Yogurts with aspartame had better body, texture, mouthfeel, and acceptance. Skriver et al. ${ }^{41}$ observed that the sensory texture of stirred yoghurt varied with different fermentation time-temperature combinations, dry matter content, heat treatment of milk, and composition of starter organisms.

Guven and Karaca ${ }^{42}$ studied the effect of different sugar levels 18, 20, and 22 percent and fruit content 15,20 , and 25 percent on the sensory 
parameters of frozen yoghurt. Sensory evaluation was done on colour, appearance, structure, taste, smell, and consistency at a 20-point scale by five expert panel members. Frozen yoghurt with 22 percent sugar and 25 percent fruit concentrations was most preferred by the panel members. According to Mani-Lopez et al., ${ }^{43}$ yoghurt with L. casei had $\mathrm{pH} 4.11$ was better perceived by the sensory panels because of its less acidic nature than control yoghurt of $\mathrm{pH} 3.96$.

\section{CONCLUSION}

Microbial fermentation, chemical synthesis, and enzymatic conversion are the different techniques used to make mannitol. Although chemical methods are the most common for producing mannitol, microbial fermentation has several advantages enabling it to be produced on a large scale. Heterolactic fermenters, Leuconostoc species are the most significant among them. As a result, Leuconostoc species like Leuconostoc pseudomesenteroides appear to be appropriate hosts for mannitol production, according to the present study. The higher mannitol synthesis allows the manufacturing of low-calorie fermented dairy products, which improve its application in healthy diets. In addition, microbial and chemical quality parameters of the functional yoghurt prepared here were in the safe and acceptable zone. The findings from this study indicate that Leuconostoc pseudomesenteroides can be added to the standard culture to develop low-calorie yoghurt with acceptable sensory, chemical, and microbial quality.

\section{ACKNOWLEDGMENTS}

The authors are thankful to the Director, Academic, and Research, and Kerala Veterinary and Animal Sciences University (KVASU), India for the financial support and facilities provided.

\section{CONFLICT OF INTEREST}

The authors declare that there is no conflict of interest.

\section{AUTHORS' CONTRIBUTION}

All authors listed have made a substantial, direct, and intellectual contribution to the work and approved it for publication.

\section{FUNDING}

None.

\section{DATA AVAILABILITY}

All datasets generated or analyzed during this study are included in the manuscript.

\section{ETHICS STATEMENT}

Not Applicable.

\section{REFERENCES}

1. Popkin BM, Adair LS, Ng SW. Global nutrition transition and the pandemic of obesity in developing countries. Nutr Rev. 2012;70(1):3-21. doi: 10.1111/j.17534887.2011.00456.x

2. Comerford KB, Miller GD, Boileau AC, Schuette SNM, Giddens JC, Brown KA. Global Review of Dairy Recommendations in Food-Based Dietary Guidelines. Front Nutr. 2021;8:671999. doi: 10.3389/ fnut.2021.671999

3. Widyastuti Y, Febrisiantosa A, Tidona F. HealthPromoting Properties of Lactobacilli in Fermented Dairy Products. Front Microbiol. 2021;12:673890. doi: 10.3389/fmicb.2021.673890

4. Rizzoli R. Dairy products and bone health. Aging Clinical and Experimental Research. 2022;34(Suppl 1):9-24. doi: 10.1007/s40520-021-01970-4

5. Yuzbashian E, Asghari G, Mirmiran P, Chan CB, Azizi F. Changes in dairy product consumption and subsequent type 2 diabetes among individuals with prediabetes: Tehran Lipid and Glucose Study. Nutr J. 2021;20(1):88. doi: 10.1186/s12937-021-00745-x

6. Wisselink HW, Weusthuis RA, Eggink G, Hugenholtz J, Grobben GJ. Mannitol production by lactic acid bacteria: A review. International Dairy Journal. 2002;12(2-3):151-161. doi: 10.1016/s09586946(01)00153-4

7. Zhang M, Gu L, Cheng C, et al. Recent advances in microbial production of mannitol: Utilization of low-cost substrates, strain development and regulation strategies. World J Microbiol Biotechnol. 2018;34(3):41. doi: 10.1007/s11274-018-2425-8

8. Hatti-Kaul R, Chen L, Dishisa T, Enshasy HE. Lactic acid bacteria: From starter cultures to producers of chemicals. FEMS Microbiol Lett. 2018;365(20):213. doi: 10.1093/femsle/fny213

9. Park YC, Oh EJ, Jo JH, Jin YS, Seo JH. Recent advances in biological production of sugar alcohols. Curr Opin Biotechnol. 2016;37:105-113. doi: 10.1016/j. copbio.2015.11.006

10. Lee SJ, Jeon HS, Yoo JY, Kim JH. Some Important Metabolites Produced by Lactic Acid Bacteria Originated from Kimchi. Foods. 2021;10(9):2148. doi: 10.3390/foods10092148

11. Tamine AY, Robinson RK. Yoghurt Science and Technology. Woodhead Publishing. 2004:76.

12. AOAC. Official methods of analysis. (15 th Ed) Association of analytical chemist. Washington DC. 1990.

13. Wu H, Hulbert GJ, Mount JR. Effects of ultrasound on 
milk homogenization and fermentation with yogurt starter. Innov Food Sci Emerg Technol. 2000;1(3):211218. doi: 10.1016/S1466-8564(00)00020-5

14. Wehr HM, Frank JF. Standard methods for the examination of dairy products. Washington, DC: American Public Health Association. 2004:190.

15. Larmond E. Laboratory methods for sensory evaluation of food. Research Branch, Canada Dept. of Agriculture. 1977.

16. Sanchez J. Colorimetric assay of alditols in complex biological samples. J Agric Food Chem. 1998;46(1):157160. doi: 10.1021/jf970619t

17. Otgonbayar GE, Eom HJ, Kim BS, Ko JH, Han NS. Mannitol production by Leuconostoc citrum KACC91348P isolated from kimchi. J Microbiol Biotechnol. 2011;21(9):968-971. doi: 10.4014/ jmb.1105.05034

18. Jung JY, Lee SH, Lee HJ, Seo HY, Park WS, Jeon CO. Effects of Leuconostoc mesenteroides starter cultures on microbial communities and metabolites during kimchi fermentation. Int J Food Microbiol. 2012;153(3):378387. doi: 10.1016/j.ijfoodmicro.2011.11.030

19. Rice T, Sahin AW, Lynch KM, Arendt EK, Coffey A. Isolation, characterisation and exploitation of lactic acid bacteria capable of efficient conversion of sugars to mannitol. Int J Food Microbiol. 2020;321:108546.

20. Helanto $M$, Aarnikunnas J, von Weymarn N, Airaksinen U, Palva A, Leisola M. Improved mannitol production by a random mutant of Leuconostoc pseudomesenteroides. J Biotechnol. 2005;116(3):283294. doi: 10.1016/j.jbiotec.2004.11.001

21. Dwivedi BK. Low Calorie and Special Dietary Foods. CRC Press. 1978.

22. Yun JW, Kim DH. A comparative study of mannitol production by two lactic acid bacteria. J Ferment Bioeng. 1998;85:203-208. doi: 10.1016/S0922338X(97)86768-2

23. Grobben GJ, Peters SW, Wisselink HW, et al. Spontaneous formation of a mannitol-producing variant of Leuconostoc pseudomesenteroides grown in the presence of fructose. Appl Environ Microbiol. 2001;67(6):2867-2870. doi: 10.1128/AEM.67.6.28672870.2001

24. Chandan RC, Gandhi A, Shah NP. Yogurt: Historical background, health benefits, and global trade. In Yogurt in health and disease prevention. Academic Press. 2017:3-29.

25. Benedict FG, Fox EL. A method for the determination of the energy values of foods and excreta. Journal of Biological Chemistry. 1925;66:783-799. doi: 10.1016/ s0021-9258(18)84783-4

26. Kroger M, Weaver JC. Confusion about yogurtcompositional and otherwise. Journal of Milk and Food Technology. 1973;36(7):388-391. doi: 10.4315/00222747-36.7.388

27. AOAC. Official Methods of Analysis. (18 ${ }^{\text {th }}$ Ed). Association of Official Analytical chemists, Gaithersburg, MD, USA. 1995.

28. Smit LE, Schonfeldt HC, de Beer WH. Comparison of the energy values of different dairy products obtained by various methods. J Food Compost Anal. 2004;17 (3-4):361-370. doi: 10.1016/j.jfca.2004.02.006
29. Salman M, Khaskheli M, Ul-Haq I, et al. Comparative studies on nutritive quality of buffalo and cow milk. International Journal for Research in Applied and Natural Science. 2014;2(12):69-78.

30. USDA. National Nutrient Database for Standard Reference. 1 April 2018. Software v.3.9.5.1_2018-0923. https://data.nal.usda.gov/dataset/usda-nationalnutrient-database-standard-reference-legacy-release

31. Younus S, Masud T, Aziz T. Quality evaluation of market yoghurt/dahi. Pak J Nutr. 2002;5:226-230. doi: 10.3923/pjn.2002.226.230

32. Joseph OJA, Joy EO. Physico-chemical and sensory evaluation of market yoghurt in Nigeria. Pakistan Journal of Nutrition. 2011;10:914-918. doi: 10.3923/ pjn.2011.914.918

33. Nazni P, Komathi K. Quality evaluation of the fruit pulp added yoghurt. Int J Agric Res. 2014;1:48-54.

34. Foda MI, El-Aziz MA, Awad AA. Chemical, rheological and sensory evaluation of yoghurt supplemented with turmeric. Int J Dairy Sci. 2007;2:252-259.

35. Roy DKD, Saha T, Akte M, Hosain M, Khatun H, Roy MC. Quality Evaluation of Yogurt Supplemented with Fruit Pulp (Banana, Papaya, and Water Melon). Int J Nutr Food Sci. 2016;4(6):695-699. doi: 10.11648/j. ijnfs.20150406.25

36. Ranasinghe JGS, Perera WTR. Prevalence of Lactobacillus bulgaricus and Streptococcus thermophilus stability in commercially available yogurts in Srilanka. Asian Journal of Medical Science. 2016;7(5):97-101. doi: 10.3126/ajms.v7i5.14326

37. Arnott DR, Duitschaever CL, Bullock DH. Microbiological evaluation of yogurt produced commercially in Ontario. Journal of Milk and Food Technology. 1974;37(1):11-13. doi: 10.4315/0022-2747-37.1.11

38. Mohammad EEB, El-Zubeir IEM. Chemical composition and microbial load of set yoghurt from fresh and recombined milk powder in Khartoum State, Sudan. International Journal of Dairy Science. 2011;6:172-180. doi: 10.3923/ijds.2011.172.180

39. McGregor JU, White $\mathrm{CH}$. Effect of sweeteners on the quality and acceptability of yoghurt. J Dairy Sci. 1986;69(3):698-703. doi: 10.3168/jds.S00220302(86)80458-1

40. Farooq K, Haque ZU. Effect of sugar esters on the textural properties of non-fat low-calorie yogurt. J Dairy Sci. 1992;75(10):2676-2680. doi: 10.3168/jds. S0022-0302(92)78029-1

41. Skriver A, Holstborg J, Qvist KB. Relation between sensory texture analysis and rheological properties of stirred yogurt. Journal of Dairy Research. 1999;66(4):609-618. doi: $10.1017 /$ S0022029999003763

42. Güven $M$, Karaca $O B$. The effects of varying sugar content and fruit concentration on the physical properties of vanilla and fruit ice-cream-type frozen yogurts. Int J Dairy Technol. 2002;55(1):27-31. doi: 10.1046/j.1471-0307.2002.00034.x

43. Mani-Lopez E, Palou E, Lopez-Malo A. Probiotic viability and storage stability of yogurts and fermented milks prepared with several mixtures of lactic acid bacteria. J Dairy Sci. 2014;97(5):2578-2590. doi: 10.3168/ jds.2013-7551 